\title{
Community Dynamics of Tanjung Obit Village, the Bacan Island, South Halmahera: A Social Resilience Perspective Kharirotul Suhaila ${ }^{1}$, Suherman ${ }^{2 *}$ \\ ${ }^{1}$ Departemen of Fisheries, Faculty of Agriculture, Gadjah Mada University, Yogyakarta, Indonesia ${ }^{2}$ Department of Chemistry, Faculty of Mathematics and Natural Sciences, Universitas Gadjah Mada, Yogyakarta, Indonesia
}

Submitted: April $9^{\text {th }}$ 2021; Revised: August $4^{\text {th }}$ 2021; Accepted: September $4^{\text {th }} 2021$

Keywords:

Dynamics

Social resilience

Natural resource potential

\begin{abstract}
Tanjung Obit Village is one of the villages in Bacan Island, South Halmahera. Recently, Tanjung Obit has socially and economically is developing rapidly because its main economic activities are driven by gold and bacan stone mines. Besides this, Tanjung Obit Village has the potential of natural resources in the form of plantations and fisheries which are very abundant. Mining activities and natural resource management activities affect people's lives there, especially in terms of the economic aspect. The study aimed to understand and analyze the social resilience of the community. The data collection was conducted through interviewing community leaders, asking the village residents to complete a questionnaire and field observations of the village. The findings of the study showed that in their daily life, people had maintained their social and social resiliencies. In terms of the economic aspect, the optimization of natural resources potentials was very important to improve their social welfare. In addition, by implementing the four aspects of social resiliencies comprising mimicking, adaptive, and transformative capacities as well as local wisdom, Tanjung Obit's people had survived and been capable of developing themselves further in the future.
\end{abstract}

\section{INTRODUCTION}

President Jokowi has designated 122 districts as underdeveloped regions for 2015-2019. The stipulation contained in the Presidential Regulation (Perpres) Number 131/2015 concerning the Stipulation of the Underdeveloped Areas for 2015-2019. Underdeveloped areas are regencies whose people and regions are less developed than other regencies on a national scale. It is challenging to reach these areas due to their geographical characteristics. They are in remote locations in the interior part of the region. These areas have hills, mountains, islands, coasts, and small islands or other geomorphological factors, making it difficult to reach them by both transportation and communication networks (Bappenas, 2008). Botang Lomang Islands is a sub-district in the Bacan Island cluster in South Halmahera Regency, North Maluku Province. These areas consist of regencies that are considered underdeveloped based on the provisions about the required indicators and sub-indicators that are regulated by ministerial regulations.

This determination is in stark contrast when viewed from the perspective of its natural resource wealth. Even though it holds the title of an underdeveloped area, this area's natural resource potential is very abundant. Ecologically, South Halmahera Regency, with its inhabitants relying on agriculture and fisheries (BPS, 2017), has high potential local genetic resources for various agricultural and plantation crops. Different fisheries potentials are in the forms of marine biota commodities as well as conservation and ecotourism destinations. In addition, the possibility that exists is crop plantations such as nutmeg, walnuts, coconut, and sugar palm. Arenga pinnata (merr), which is a palm plant, is one of the genetic resources in the tropics.

ISSN 2460-9447 (print), ISSN 2541-5883 (online)

${ }^{*}$ Corresponding author : Suherman

Department of Chemistry, Faculty of Mathematics and Natural Sciences, Universitas Gadjah Mada, Bulaksumur, Senolowo, Caturtunggal, Depok Sleman 55281, Special Region of Yogyakarta, Indonesia

Email: suherman.mipa@ugm.ac.id 
In this regard, backwardness will be seen from community social resilience concerning their natural resources. Community social resilience is a community's ability to deal with risks due to change, economy, and politics. According to Keck and Sakdapolrak (2013), an organization has social resilience if it has the following dimensions: 1 . Coping capacities, namely social actors' ability to cope with and solve all kinds of problems; 2. Adaptive capacities, namely the ability to learn from past experiences and adapt to future everyday life; 3. Transformative capabilities, namely the ability to assemble institutions that promote individual welfare and sustainable community resilience against future crises. These three dimensions complement the fourth dimension, namely, developing local wisdom in maintaining natural and social resources.

The local community's ability will be seen as an initial picture in identifying the social resilience of the local community. Therefore, some of the problems raised are related to community welfare in connection with social resilience conditions and identifying programs that can be carried out in the area. This study aimed to identify the requirements for social resilience and development programs to optimize the village's existing wealth potential to boost the development of the village under the circumstance's natural resources potentials in the future.

\section{METHOD}

The data were collected from 27 June 2018 to 8 August 2019 in Tanjung Obit Village, Botang Lomang Islands Subdistrict (Bacan Island), South Halmahera Regency, North Maluku Province. This study was a descriptive analysis that examined the local community's social life sources. The data were obtained through literature study, interviews, observations, and group discussions. Interviews were conducted with existing community leaders and associations regarding the social structure of the people in Tanjung Obit, their jobs, education level, characteristics, and mindset about their culture and future. According to Miles and Huberman (2009), in-depth interviews should be carried out when the context is considered appropriate to obtain data that has depth and can be done frequently according to the researcher's needs regarding the clarity of the research problem that is focused on. In addition, group discussions were also held together with questionnaire completion to complete the qualitative and quantitative information. Group discussions were held repeatedly in Tanjung Obit Village, Botang Lomang Islands District, by inviting the community consisting of youths and girls, village officials, and community leaders. The topics that were discussed were the four dimensions of the community's social resilience, social welfare, and the efforts needed in community development.

\section{RESULT AND DISCUSSION}

\subsection{Education level}

Table 1. Education level in Tanjung Obit

\begin{tabular}{lll}
\hline No & \multicolumn{1}{c}{ Education Level } & \multicolumn{1}{c}{ Total } \\
\hline 1 & No Schooling & 34 peoples \\
2 & Did not complete elementary school & 254 peoples \\
3 & Graduated from elementary school & 39 peoples \\
4 & Graduated from junior high school & 32 peoples \\
5 & Completed high school & 26 peoples \\
6 & Completed diploma & 2 peoples \\
7 & Undergraduate & 4 peoples \\
\hline
\end{tabular}

The education level of the population in Tanjung Obit Village is classified as low, most of whom did not complete elementary school (SD), totaling 254 people $(46.29 \%)$, and as many as 34 people $(25.12 \%)$ are not attending school. This is due to the limited access to education that is accessible to the population. Education is a tricky issue here because the knowledge level of Tanjung Obit residents is only equal to Elementary School (SD) education. To continue to a higher level, people have to pay a lot of money because they have to continue to Labuha City or another island. The education levels of the population in Tanjung Obit are presented in Table 1 (Tanjung Obit Village Document, 2017).

\subsection{Religion}

The residents of Tanjung Obit Village can be described as almost entirely adherents of Islam according to the local community leader. This is due to the influence of its history, namely the expansion of Ternate and Tidore, which were Islamic kingdoms. Another thing that contributed to Islam adoption in Tanjung Obit was the riot in Maluku in 1999-2001 between religious groups. In this area, Islam religion has been powerful. There were almost no residents of other faiths. The existing religious facilities are in the form of a mosque. Religion also plays a role in influencing the order of the community's life. The use of forest resources in Tanjung Obit has been also influenced by religion. In general, people meet their needs for protein from only sea products. They do not consume the meat of reptiles and amphibians because they are forbidden in the teachings of Islam.

Although most of the people in Tanjung Obit are Muslims, they still adhere to magical things. The strong dependence of the residents on nature causes these people to believe that other forces other than God have influences on their life although small.

\subsection{Health}

The health condition of Tanjung Obit residents shows that the community has not prioritized cleanliness, to say the least. Based on the information 
gathered from the Tanjung Obit Village head, this is reflected in the uneven ownership of a private bathroom in each house. The observation results showed that there are only about ten houses out of the total that had private bathrooms and toilets. The community still shares public bathroom facilities. This means that these people have been very susceptible to disease transmission due to the sharing of public bathrooms.

In general, the Tanjung Obit community's physical condition is vital due to the natural conditions they face every day and their work habits. However, public awareness of medical treatment if they are infected with a disease is still low. This causes a relatively high mortality rate due to $\mathrm{TB}$ disease indications, prolonged illness, and the susceptibility of under-five mortality. Health facilities in Tanjung Obit have been also fairly minimal. There is only one village polyclinic with one midwife working for the local government to deal with health problems. Education about health in the village is still very much needed and needs to be fostered regularly to improve the community's health level.

\subsection{Socio-cultural aspect}

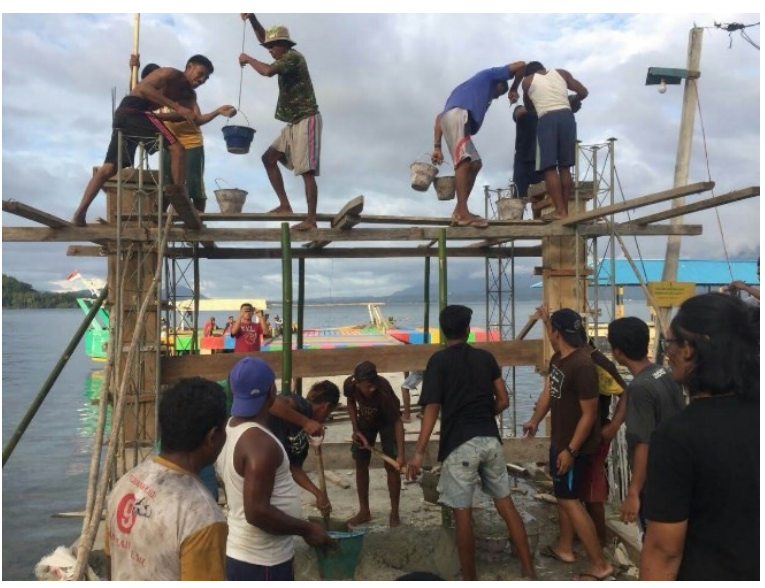

Figure 1. Villagers working together to build the Tanjung Obit monument

In living their lives, the people of Tanjung Obit abide by their cultural characteristics and local wisdom. One definition states that local culture and knowledge are local (regional) ideas that are wise, full of learning, and have good values, embedded in and followed by community members. In anthropology, this is known as a local genius, and it is said that local wisdom (local genius) is a tradition that has been traditional in an area. The people of Tanjung Obit have a culture of maintaining a high sense of solidarity as shown in Figure 1. This culture can be connected with the custom of ngale se cara sere se doniru, namely the traditions of the sultanate of Ternate, which means good habits, and it has been useful in maintaining a harmonious life as a unity as long as they do not conflict with applicable laws such as the procedures for social harmony in social life (Pettalongi, 2012). On a non-formal basis, the population has recognized and cultivated the babari institution, an institution for cooperation among community members or community groups. If people build houses, gardens, or organize parties, other community members would help them without being paid. In its current development, babari is still being implemented although it is not as complete as in the past. This means that the characteristic of solidarity and cooperation among the community members has always been nurtured. The factor that has strengthened these characteristics is the narrow area of their dwelling so that they have a strong sense of belonging to one another and a powerful sense of belonging. Currently, the social network of the Tanjung Obit community is adequate. When this research was conducted, there were already village apparatus composition and staff, PKK (Family Wellbeing Program) management, and youth organizations. However, their implementations within the people's daily activities are yet to be realized.

The natural resource potential of Tanjung Obit Village and its surroundings is preserved sustainably because the utilization of natural resources is based on traditional knowledge and wisdom. With its conventional wisdom, the balance of forest and marine environmental ecosystems has been maintained and sustainable for a long time because the utilization of forest and aquatic products is within the limits of natural carrying capacity. The community only uses a small part of these resources and is still using traditional methods, so that the existing potential has not been fully explored and utilized.

The community also still maintains its unique culture. One of them is the culture of chewing betel nuts. This is a community tradition with its elemental composition of betel leaf, areca nut, gambier, lime, and tobacco. The piece is wrapped in betel leaf, which is then chewed. According to the interview results, chewing betel nuts can provide benefits, namely, it can substitute smoking and can be an activity in spare time and eliminate bad breath. Chewing betel nut is passed down from generation to generation because this activity can strengthen teeth. Based on research conducted in England on immigrants from South Asia who chewed betel nut, it was found that they chewed betel nut because it provided a refreshing taste, functioned as a snack, helped relieve stress, and was believed to strengthen teeth and gums (Flora et al., 2012).

\subsection{Livelihood and the economy}

In general, the people of Tanjung Obit search for mining products on Buru Island (gold), Obi Island (gold and obi stones), Kasiruta Island (bacan stones), and other islands around Maluku. The gold mine on Buru Island, which is on Mount Botak, began to be busy since 2012 when the gold ore's abundant potential was 
discovered. Since then, the indigenous people around Mount Botak and immigrant communities have started to extract/dig the area where there is an expanse of gold ore on Mount Botak. The money that the people get from these mining activities varies greatly depending on their luck; this is also true for the gold mining area on Obi Island.

Apart from gold, mining activities that are the community's favorite livelihood are bacan stone mining on Kasiruta Island, a part of the Bacan Islands. The economic value of this type of Chrysocolla quartz stone, better known as bacan stone, is very high and now occupies a place as a precious stone hunted by collectors (Purwanto, 2017). If lucky, a group of people can earn up to hundreds of millions of rupiahs from bacan stones. However, to get this stone, the community must go through challenging and dangerous terrain and a risky mining process. Bacan stone is mined from dug holes that are dug manually. The holemaking process is very difficult. Likewise, the terrain the people have to go through before reaching the mining location is treacherous.

Apart from mining, the people who live in Tanjung Obit have daily economic activities of planting and fishing. However, from these economic activities, residents also do activities such as gathering sago, making copra, making palm sugar, and trading. The village's soil conditions are fertile and hilly, and these support many crops that can be used as trading commodities as shown in Figure 2. Plant products are generally only used or consumed by the villagers themselves, sold among them, and some sold to other islands or in Labuha City. The community plantation system in Tanjung Obit is permanent, which is related to land ownership and control systems. Plantation activities are usually carried out on Nusara and Nusa Deket, which are uninhabited but very fertile islands.

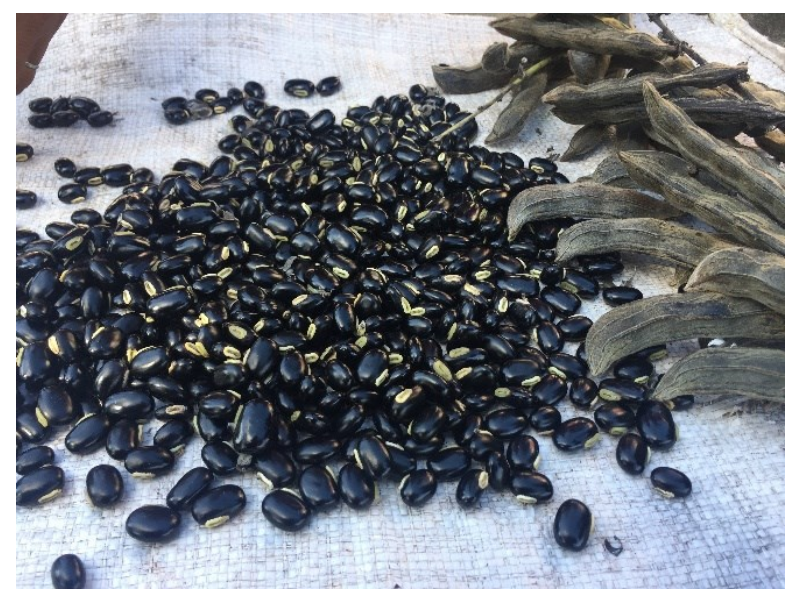

Figure 2. Tanjung Obit plantation product

The waters around Tanjung Obit Village are rich in seafood in the forms of various types of fish (tuna, mackerel, samandar, bobara, kurisi, baronang, shark, moonak, lalosi, anchovies, shrimp, grouper, and lobster). The village is surrounded by the sea and blocked by small islands around it makes the waves in this area calm. This means that it makes it very easy for people to catch fish. The unfortunate thing is that the community has not considered the fishery sector as their primary life support. On average, daily fishing activities are only done to meet personal and family consumption. There are only a few residents who have relied on the fishery as their daily economic activity. Fishery activities that have been carried out still use traditional tools, namely nets, spears, bows and arrows, fishing rods, and fishnets. Several people use nets to raise marine fish. Tanjung Obit Village also has floating net cages established by the local government, but this activity still develops slowly because the community is not very interested in taking advantage of it. The factor contributing to this behavior is the low selling price of fish at the fishermen's level because fish sales are still limited in the village. The selling price is influenced not only by the quality of the fish but also by the market's supply and demand. The community is also not very familiar with processed fishery products such as fish balls, fish nuggets, etc. Tanjung Obit contains marine resources that are of high economic value and can be sustainable in the future if its utilization continues to use sustainable principles.

Another activity of the community in Tanjung Obit Village is making copra, which is made of coconut (Cocos nocifera) shells. Copra is made by drying coconut shells using smoke. Copra is popular in this village because there is a large number of coconut trees that grow in almost all parts of the Tanjung Obit mainland. Copra-making activities are carried out in fields located separately from residential areas. In addition to copra, the community also makes palm sugar and plant cassava. However, the main difficulty of these products is in terms of their marketing. This is similar to research conducted on Gag Island. Marketing these products to the mainland is considered unprofitable because they have low values due to their improper forms and packaging. Moreover, accessing the mainland is not easy as the main island, which is Labuha City, can only be reached by sea transportation, and vehicle access in the city is limited.

The means of communication connecting Tanjung Obit with the outside world is satellite signals whose network is not so stable. Meanwhile, public information that can be accessed using radios and televisions is limited as these electronic devices are only owned by a few residents. Apart from having to use a satellite dish, the availability of electricity is also minimal. People enjoy electricity at night between 18.30 and 23.30 WIT (Eastern Indonesian Time) produced suing generators. Limited accessibility to communication and 
transportation is one factor behind the hampered development of this village (Hastanti and Triantoro, 2012).

\subsection{Social Resilience}

The four aspects of social resilience consist of firstly coping capacities, namely social actors' ability to overcome and solve various problems. This can be related to Social Protection for Persons with Social Welfare Problems (PMKS), which includes many types of persons, namely vulnerable families, families living in disaster-prone areas, and the poor. The three are related to each other, especially concerning several ethnic groups whose lives have been isolated. The people of Tanjung Obit Village have generally been able to overcome social welfare problems. Social protection for PMKS is realized through the values applied in their social life, especially in babari. The life pattern of the people there that is still cooperative and has a high sense of brotherhood helps minimize social welfare problems.

Moreover, the people of Tanjung Obit Village do not differentiate between one ethnic group and another. Tanjung Obit's economy's central supporting aspect is in the forms of gold and bacan stone mining activities. These economic activities are considered to have the most significant results for the people's economy, including for the construction of their houses and other facilities and sending their children to school. However, what needs to be known is that mining activities have a high level of uncertainty balanced with a very high risk. This is because the mining area managed by the villagers is illegal, and it is owned by the people, not belonging to a company. Nevertheless, the villagers manage the mining area well as they pay attention to and improve work safety, and they maintain sustainability and the existing ecosystem (Tuaputy et.al., 2014). From a sustainability perspective, ores recovered through mining are a natural resource that cannot be renewed if the source has been damaged or has run out in the future.

Tanjung Obit Village is blessed with a wealth of natural resources in the fishery and very fertile plantations. The community has not fully realized this potential, so that their utilization is minimal, especially in the fishery sector. This is ironic as the potential available in the fishery and marine sub-sector (standing stock) in North Maluku is 694,382.48 tons per year. The skipjack population and tuna fish available (standing stock) are estimated at 268,382.5 tons per year (Marasabessy, 2010).

To improve social resilience in the economic sector, the fishery sector can be used as one of the pillars along with the mining sector or can even replace the mining sector in the future. This is analyzed from the availability of sources and their sustainability. The gold mine and the bacan stone mine have decreased in value over time, and their risk has increased. Therefore, changing the people's mindset, that is to shift from mining activities to sustainable plantation and fishery activities will help boost social resilience in the economic sector.

Second, adaptive capacities, which are the ability to learn from past experiences and adapt to future everyday challenges. This can be reflected in the management of conflicts that occur in the community. By learning from past experiences, the socio-political conditions have been very stable in recent years, making Tanjung Obit conditions safe and orderly. Conflicts are often resolved in groups. If it is related to adat (custom), then the respective tribal leaders or community leaders will resolve it according to the adat Sometimes, solving a problem requires mediation facilitated by the police and local government; this is to make sure that the conflicts do not last or do not continue.

The third is transformative capacities; this is the ability to form institutions that promote individual welfare and sustainable community resilience against future crises. This can be reflected in social participation in organizations shown by social institutions or social and religious organizations. In Tanjung Obit Village, social institutions include religion (Islam), education (there is one SD), health (there is a policy - village polyclinic), economy (shops and buying and selling), politics (voting in elections), and community associations (PKK and youth organizations). Through social participation, the potential of Tanjung Obit Village, especially its plantations and fisheries, can be utilized optimally and sustainably.

Fourth, the maintenance of local wisdom depends on the existence of residents and migrants. Among the local population, there are still robust customary arrangements related to various traditional ceremonies. Now, these arrangements are more often associated with the religion's role, so that the community and religious leaders can carry out their respective duties and functions. The division is outlined because traditional leaders know and implement customary rules in the community, such as customary rights, marriage, and other traditional ceremonies. Meanwhile, religious leaders carry out their duties related to their religious activities, especially in wedding ceremonies.

Maintaining local wisdom in terms of the utilization of natural resources can also be used as supervision so that environmental sustainability can be claimed even although it is used for development following the principles of Sustainable Development Goals. Sustainable Development Goals are seen as a sustainable development paradigm that talks about how evolution can meet the present needs without 
destroying or neglecting the rights of future generations. The aspect of social resilience and how they have been implemented in the Tanjung Obit Village can be summarized in Table 2.

Table 1. Four aspects of social resilience

\begin{tabular}{ll}
\hline Social Resilience Aspects & \multicolumn{1}{c}{ Implementation } \\
\hline Social Resilience Aspects & Implementation \\
Copying Capacities & Through babari \\
Adaptive Capacities & Group deliberations \\
Transformative Capacities & $\begin{array}{l}\text { Shaping institutions and } \\
\text { organizations }\end{array}$ \\
Local Wisdom & Maintaining culture and traditions
\end{tabular}

\section{CONCLUSION}

From the research and discussion above, some conclusions can be made. First, Tanjung Obit Village is not suitable to be categorized as a disadvantaged district. However, it is a fact that geographically this area is an archipelago; therefore, it is left behind due to the difficulties experienced by the residents living in its remote areas to get good access to information and infrastructures. Second, the community's social resilience maintains its cultural values as a form of social resilience, especially concerning the maintenance of local pearls of wisdom and traditions that still support the villagers' cultural life such as babari, kinship functions, and good tribal habits. Third, community development programs need to be carried out in local communities to improve social welfare. Such activities will give essential meaning to the community as these can facilitate the community to empower themselves. Fourth, with all the natural resource potentials Tanjung Obit has, combined with the villagers' social capacities, it is believed that this village has a great opportunity to develop in the future.

\section{REFERENCES}

Adrianto, L. (2005). Pembangunan dan Pengelolaan Pulau-Pulau Kecil yang Berkelanjutan (Sustainable Small Island Development and Management). Working Paper. Center for the Study of Coastal and Ocean Resources, Institut Pertanian Bogor. Bogor. Indonesia.

Bengen, D.G., Retraubun, A. (2006). Menguak realitas dan urgensi pengelolaan berbasis eko-sosio sistem pulau-pulau kecil. Center for Coastal and Marine Learning and Development. Bogor.

[BPS] Central Bureau of Statistics of South Halmahera Regency. (2017). South Halmahera in Numbers 2017.

Flora, M.S, Tylor, C., Rahman, M. (2012). "Betel Quid Chewing and Its Risk Factors in Bangladeshi Adults". WHO Southeast - Asia Journal of Public Health, 2012:1(2):162-181.

Hastanti, B.W., Triantoro, R. (2012). Kondisi Sosial Ekonomi Dan Budaya Masyarakat Sekitar Kawasan Konservasi: Studi Kasus Di Pulau Gag, Raja Ampat, Papua Barat. Wallace Journal of forestry Research, 2012: 1(2): 149 -164.
Keck, M., Sakdapolrak, P. (2013). What Is Social Resilience? Lessons Learned and Ways Forward, in Jurnal Erdkunde, Department of Geography University of Bonn, Germany, 2013: 67(1): 5-19.

Marasabessy, M. D. (2010). Sumberdaya Ikan di Daerah Padang Lamun Pulaupulau Derawan, Kalimantan Timur. Oceanographic Research Center - LIPI. 2010: 36(2): 193-210.

Miles, B., Huberman, A.M. (2009). Qualitative data analysis. Thousand Oaks (CA): Sage Publications Ltd.

Pettalongi, S. (2012). Adat Segulaha Dalam Tradisi Masyarakat Kesultanan Ternate. El Harakah Journal, 14(2).

Purwanto, S. (2017). Analisis Karakteristik Kolektor dan Proses Pembelian Batu Akik dengan

Pendekatan Leisure Study. Maksipreneur Journal, 2017: 7(1): 31-47.

Tuaputy, U. Kumala, P. I. Suzy, A. (2014). Eksternalitas Pertambangan Emas Rakyat di Kabupaten Buru Maluku. Journal of Agriculture, Resource, and Environmental Economics, 2014: I(I), 71-76. 